HUOM! Tämä on alkuperäisen artikkelin rinnakkaistallenne. Rinnakkaistallenne saattaa erota alkuperäisestä sivutukseltaan ja painoasultaan.

Käytä viittauksessa alkuperäistä lähdettä:

M. Drake, R. Kauppinen (2021) NEW TECHNOLOGY - A NEW APPROACH TO FURTHER VOCATIONAL TRAINING?, ICERI2021 Proceedings, pp. 8005-8011.

https://doi.org/10.21125/iceri.2021.1811

PLEASE NOTE! This in an electronic self-archived version of the original article. This reprint may differ from the original in pagination and typographic detail.

Please cite the original version:

M. Drake, R. Kauppinen (2021) NEW TECHNOLOGY - A NEW APPROACH TO FURTHER VOCATIONAL TRAINING?, ICERI2021 Proceedings, pp. 8005-8011.

https://doi.org/10.21125/iceri.2021.1811

(C) 2021 IATED. All rights reserved. 


\title{
NEW TECHNOLOGY - A NEW APPROACH TO FURTHER VOCATIONAL TRAINING?
}

\author{
Merja Drake, Raine Kauppinen \\ Haaga-Helia University of Applied Sciences (FINLAND)
}

\begin{abstract}
As a result of the rapid changes in the labour market and available career paths, people need to reshape their skills and competencies. The World Economy Forum has calculated that new technology will transform over 1 billion jobs worldwide in the next decade, and as such, there is a tremendous need to reskill the workforce. Until now, further vocational training of the workforce has taken place in educational institutions. Now, to a greater extent, big companies such as Google, Apple, Hilton, and start-ups especially, are training their own workforce. So, what is the role of higher education in the future? How could company and higher education institutions work in co-operation to reskill and train the workforce using new technology?

Virtual technology $(\mathrm{VR})$ is one of the emerging technologies that is changing the training landscapes both in companies and in educational institutions. Previous research has shown VR's potential in the educational domains, especially in medicine, aviation, arts, journalism and entertainment, but its full potential in work-based education or further vocational training and in the process by which collaborating companies and higher education institutions design, develop and create VR-based training materials have not been researched to an adequate extent.

In this paper, we discuss how companies in health care, hospitality, the home furniture and home accessories industry, the cleaning services sector, and higher education (HE) can collaboratively develop, produce and test vocational training materials created using VR technology. Our objective is to understand VR's potential as a tool for work-based training and to design the model and process of how to create training material collaboratively using the living lab method. We have chosen our example industries because they offer suitable entry-level positions to immigrants with a lack of language skills. The other challenge is that the professional background of immigrants varies quite a lot. Health care, hospitality, furniture and home accessories industries, and the cleaning services sector are suffering from labour shortages, and at the same time, we are facing the challenge of inadequate employment of immigrants.
\end{abstract}

Keywords: Virtual Reality, further vocational training, work-based training, immigrants, living lab.

\section{INTRODUCTION}

According to Pilz [1], young peoples' success in establishing their individual career paths depends on a successful entry into the labour market once they have completed their compulsory education. At the same time, it has become difficult to make a direct transition from compulsory education into initial training and the labour market. The situation facing immigrants making their own career paths is much more demanding. Four of five immigrants living in Finland are of working age; however, the employment rate of working-age immigrants is considerably lower than that of the general population. $[2,3,4$.] One challenge is that the immigrants' educational and professional backgrounds are quite varied - from lawyers and professors to people with only basic education. Many of the immigrants also face language challenges.

Our initial objective was to find out how to recognize immigrants' competencies using VR in order to reduce language-related barriers to immigrants' employability [5-7]. Nevertheless, we found that it is important to understand how immigrants could participate in work-based training and the role of HE in fostering personal growth and active citizenship of the immigrants. We also wanted to find out what kind of training material companies and HE institutions could produce together.

What is the best way to learn new competencies when your language skills are not at an adequate level? It is not easy to move into a country where the language is not familiar to you and the culture is very different from in your home country. These are challenges educators and companies face while providing training to immigrants. 
New technologies and immersive learning environments like virtual and augmented reality may offer one type of solution. VR could be particularly useful for training immigrants because instructions and the training material need not be language-based. Instead, training modules could be produced so that the correct modes of action are first demonstrated before being practiced. In addition, exercises could be repeated safely, as many times as needed, and knowledge could also be verified on a virtual world screen. The biggest obstacles to using VR have been cost and human resources. [8] Decreasing software and equipment costs are making more experiments possible; however, at the same time, some challenges might arise due to how rapidly the technology is changing [9].

However, VR is increasingly being used to deliver learning and training material, and VR's affordances are particularly relevant in fields like medicine, engineering, aviation, safety training, hospitality business and health care. Previous studies suggest that the benefits are interaction, immersion, deep concentration and real-life experience. Training situations can be either individual or collaborative, and students learn by doing. The students can actively participate in the learning process because it is an immersive experience without external distractions. VR learning can enhance interpersonal communication, and it offers fertile ground for different kinds of learning styles. [10-13]

The World Economy Forum has calculated that new technology will be transforming over 1 billion jobs worldwide in the next decade and that there is a tremendous need to reskill the workforce [14]. The question is what kind of competencies are needed in the future and what kind of vocational future training could be used in the workplace?

Competence is a combination of knowledge, skills, attitudes and abilities required in the workplace and a measure of skills and proven knowledge. Competence recognition is generally approached as a learning taxonomy, which is typically based on documents presented by students or other methods, such as transfer crediting and demonstrations. [15].

A learning taxonomy entails that learning occurs at different levels. A taxonomy is a hierarchical system; one must master lower levels before proceeding to higher levels. There are three domains or basic types of educational objectives: cognitive objectives, which involve mental processes such as memory recall and analysis; affective objectives, which involve interest, attitudes and values; and psychomotor objectives, which involve motor skills [16]. The taxonomy of learning objectives is a framework for classifying statements of what is expected or intended for students to learn as a result of the instructions [17]. Motivation is the primary factor that determines whether a student will complete a course or assignment and is highly predictive of course engagement; in turn, engagement is a strong predictor of retention [18].

We created competence recognition models using VR aimed at helping immigrants demonstrate their competencies and skills despite language barriers [5-7]. However, researchers have yet to discover the full potential of this technology. In particular, more detailed investigations should be directed towards cooperation between companies and end users in the development of VR-based training content. We justify of the creation of the models by the fact that the labour needs of the companies vary and the employees must have competencies suitable for the company. While creating training materials, different viewpoints are needed: HE professionals are familiar with the learning pedagogy, and the competencies required will come from the companies. Hager \& Gonzi [15] define pedagogy as enhancing student learning and the way in which teachers facilitate learning.

HE could help the employer understand what level of competencies are needed and required, and how competencies can be trained and tested. In turn, the companies could focus on the necessary competencies; for example, not requiring more language skills than are necessary to avoid preventing potential workers, e.g. immigrants, from obtaining jobs they're capable of doing.

\section{OBJECTIVES, RESEARCH QUESTIONS, AND METHODOLOGY}

First, our objective is to determine how companies and higher education institutions can collaboratively develop and produce work-based training materials supported by VR technology and create models according to which such cooperation can be practiced. Second, we want to find out what kind of learning material best suits our target group of immigrants.

Our research questions are as follows:

- RQ 1: How can the key competencies needed in the chosen industries be defined? 
- RQ 2: What kind of process is needed to create feasible learning material focusing on the key competencies in collaboration with the chosen industries?

To create our collaboration model, we used a user-centric living lab and developed the model in an ecosystem comprising companies from the hospitality, healthcare, furniture and home accessories industries, cleaning service sector, immigrant associations, two higher education institutions, the Helsinki Skill Center and Turku Skill Center, and immigrants. The aim of a living lab is to facilitate innovation, create new services and products, produce prototypes, and test creations in cooperation with end users [5-7].

Living labs are very useful in various situations, such as when users change their roles from passive consumers to active prosumers, to innovate and involve others with companies and other stakeholders in finding solutions to everyday problems. The following are different types of living labs: Research living labs that focus on the innovation process, Corporate living labs that focus on innovations co-created with stakeholders, Organisational living labs where organisation members innovate, Intermediary living labs in which various stakeholders innovate in cooperation in a neutral area and Time-limited living labs that close when the project ends [19].

Our living lab most closely resembles an intermediary living lab, as a number of different entities were involved in the development process.

The purpose of a living lab is to solve everyday problems and boost the economy via practice-based innovation, rapid development, and testing by users [20]. In our case, the aim was to use our living lab to develop work-based VR learning content in collaboration with the participating companies.

We chose the healthcare industry because it is experiencing a persistent shortage of workers and is projected to grow significantly (by 17 per cent) in the coming years, especially because of ageing. The healthcare industry belongs to a group of emerging occupations, i.e. those that have experienced the most growth over the previous five years. Our healthcare industry partner company is among the largest in Finland; it is over 111 years old and employs more than 20,000 people [21]. Our hospitality industry partners consist of several restaurants in the Helsinki area [4]. A cleaning service industry partner is a middle-sized company based in the Turku area. The furniture and home accessories industry partner is the international company IKEA. IKEA has conducted a special project aiming to employ several dozen migrants in the coming years.

To create the domain-specific content development model, we conducted several workshops with companies about learning objectives and the key competencies needed in their respective industries. We went through the curriculums of the degrees in the field and selected the most desirable competencies. A curriculum is a framework of student expectations and experiences that students meet in the educational process. It is a purposeful plan for many possible learning activities and desired goals. [22.]

Several taxonomies describe levels of learning and knowledge. Bloom's taxonomy is widely used and defines three domains of learning: cognitive, affective and psychomotor skills. Marzano's new taxonomy focuses more on cognitive abilities and has three main systems: the self, metacognitive, and cognitive systems [1516]. Our content model is based on both Bloom's and Marzano's taxonomies. Based on the chosen competencies and taxonomy, we wrote scripts on the contents of the learning material.

When creating content for virtual reality, it is also important to acknowledge its limitations. For example, Oculus's instruction manual discourages the use of VR for more than 30 minutes at a time. [23]. Test groups had to be familiarised with the use of VR glasses and content.

\section{RESULTS}

As we reported in the previous chapter, we conducted several workshops with the participating companies, starting with the hospitality and health care industry, to find out the most desirable competencies. Second, we created a three-step competence recognition model for the hospitality industry and a four-step equivalent for the healthcare industry using virtual reality.

After several rounds with the companies, the decision was made about the job tasks for the work-based learning material. For the hospitality industry, it was important to create work-based learning material concerning the hygiene passport, which is, according to the Finnish food authorities, Ruokavirasto, compulsory for people who work with perishable foods. [24.] The healthcare industry decided that they need work-based content about pharmaceutical distribution in elderly homes, because it is a highly 
rationed task in which fatal mistakes can occur, and it has to constantly practice it at work. The learning material was created using the Unity game motor and 360 videos. The material was created both in Finnish and in English. We tested the training material in eight different testing rounds in collaboration with immigrant associations and immigrants at Helsinki Skill Centre and Turku Skill Centre, as well as with the company's representatives, and collected the feedback. In addition, we interviewed 78 immigrants with different backgrounds about their needs and employment goals. After testing the material in the hospitality and health care industry, we got involved with the industries of new interest, furniture and home accessories, and the cleaning service sector, and we started the planning for these industries.

The model for the collaboration is shown in Picture 1. The first step was to organise a workshop and introduce the company's VR and its possibilities in work-based training, the cost of the classes (Oqulus Quest), and how to make the content using 360 videos and Unity engine motors. The second stage was to iterate the needed competencies and explore the existing curriculums and taxonomies of the field. After that, we organised the second workshop to find out the most desirable competencies and the job tasks for the pilot work-based training material. Our project group wrote scripts for the scenes to be filmed and introduced them to the companies in Workshop 3. Our project group filmed and created the content using the Unity gaming motor. In Workshop 4, the material was tested with the companies and immigrant associations.

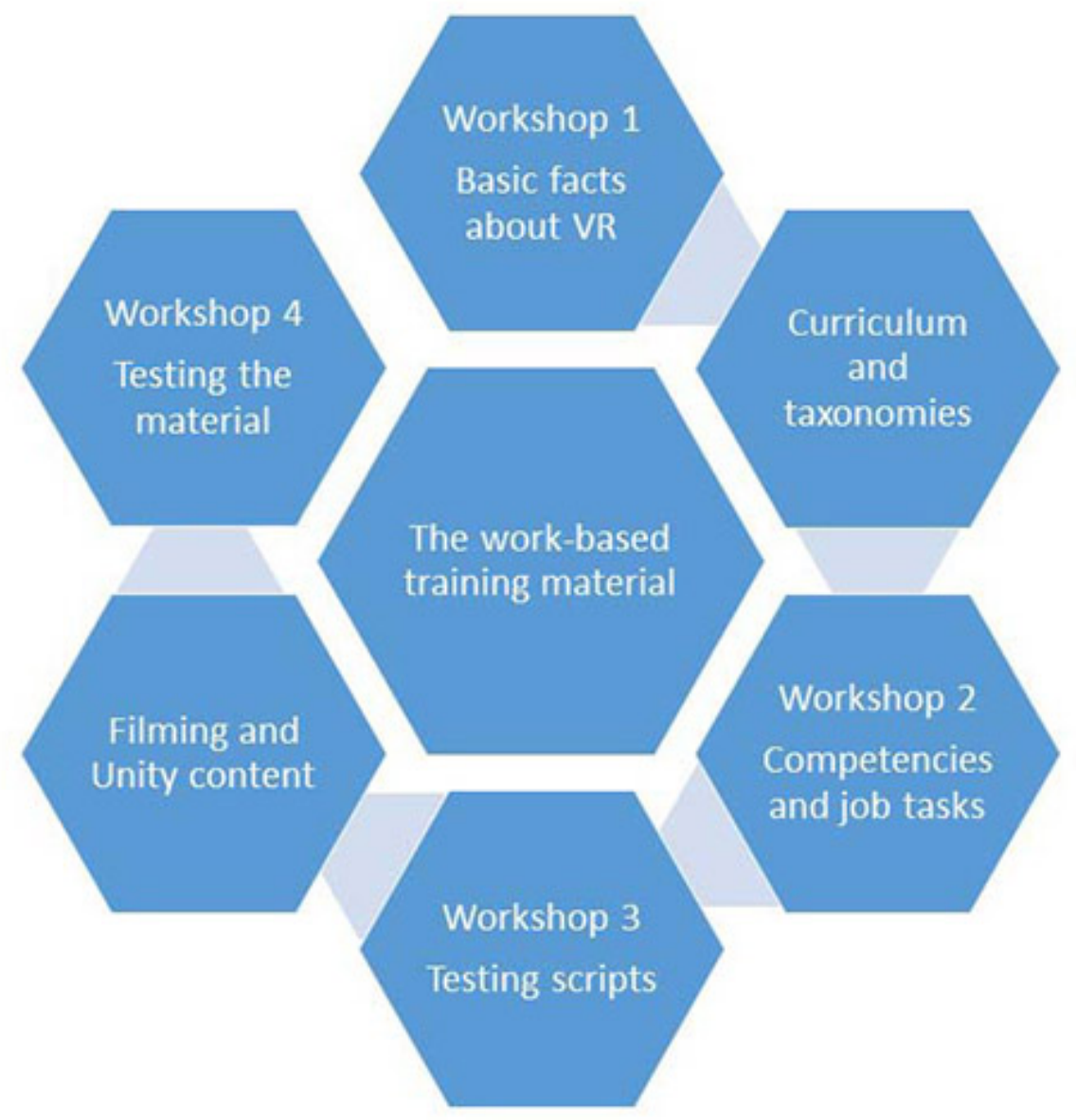

Figure 1. The model for creating work-based training material using VR in collaboration with companies and immigrant associations.

In sum, we created the content and tested it in collaboration as follows:

- Hospitality industry - three steps - restaurant walk for step one, hygiene passport for step two, and how to work in the kitchen and prepare food for step three

- Health care industry - four steps - spotting the problem for steps one and two, getting to know your workplace for step two, interacting with the difficult patient for step three, and distributing pharmaceuticals for step four. 
- Cleaning service sector - cleaning game - getting to know what the different cleaning equipment is called and learning Finnish, with a detailed round to get know your work place and how to use cleaning equipment at work

- Furniture and home accessories industry - how the values of the company appear in daily work $=>$ the script has been done; filming and editing is ongoing.

Getting content into VR format required a certain degree of coding in the Unity engine. The making of VR content has been criticised as laborious and expensive. As a final result of our project, based on our model of competence recognition and content creation, we created an excellent template for Unity. In the future, it will be much easier to create new VR content for the template without the need for any coding.

\section{CONCLUSIONS}

Our research questions were as follows: RQ 1: How can we define the key competencies needed in the chosen industries? And $R Q$ 2: What kind of process is needed to create the learning material in collaboration with the chosen industries? It was somehow difficult to find a balance between the curriculum competencies and the competencies companies really need. The curriculum competencies hold the general competencies of the industry, but some of the competencies are more specific to the workplace. The rapid change of the labour market and the new technology challenge us to consider whether vocational education should be delegated as more in the workplace. Workplaces need to reskill their workforce, but who should plan and implement the training? Big companies such as Google, Apple, Hilton, and start-ups especially, are already training their own workforce. What will the role of vocational education and HE be in the future? Markowitch \& Hefler [ ] predict that vocational education systems have become more open and have developed their access routes to higher and further education. Nevertheless, educators, companies and organisations should collaborate much more closely.

When it comes to our second question, there is no easy answer. The collaboration with the companies was not always smooth - representatives of the companies were in a constant rush and the people acting in the role changed many times. For the new people everything had to be explained from the beginning and the content designed from the scratch. In addition, filming schedules did not work because covid-19 blocked access to elderly homes and it was difficult to organise testing rounds and find immigrant to test the material.

In the beginning, company representatives did not realise the real potential of virtual reality in workbased training. Many companies asked if we could create just normal videos. They were not familiar with the cost of portable VR classes. Therefore, they needed basic information about the cost of the classes and how to create the content. After getting to know the first VR pilot material, they were amazed at how immersive virtual reality is. They became convinced that VR is technology of the future and that it is useful especially for self-training in the workplace. From the perspective of these companies, VR technology can be used for the orientation of new workers and the reinforcement of learned competencies. [ ] However, companies' expectations were somewhat too high with regard to the language skills of immigrants. They required quite good proficiency in Finnish, even if the competency required in the job tasks themselves would not have required it.

The living lab seemed to be a success (albeit a somewhat time-consuming one) as a place for designing and creating the work-based training material, and for designing the concept for the collaboration for creating work-based training material using VR.

Our next steps are to continue tests with our target group, collect the feedback and revise our training material, as well as test the usefulness of our Unity template for VR content.

\section{ACKNOWLEDGEMENTS}

This project is funded by the European Social Fund.

\section{REFERENCES}

[1] M. Pilz. . Introduction: Questions, Challenges and Method in Pre-vocational Education in European Schools Eds. Pilz, Berger \& Canning. Springer 2018. 
[2] O. Åslund, O. \& D-O Rooth. Do When and Where Matter? Initial Labour Market Conditions and Immigrant Earnings. The Economic Journal, vol. 117, no. 518, pp. 422-448, March, 2007. <https://ssrn.com/abstract=978574 or http://dx.doi.org/10.1111/j.1468-0297.2007.02024.x>.

[3] A. Eronen, V. Härmälä, S. Jauhiainen, H. Karikallio, R. Karhinen, A. Kosunen, J-P Laamanen, \& M. Lahtinen. Maahanmuuttajien työllistyminen. Taustatekijät, työnhaku ja työvoimapalvelut. (Labour Market of Immigrants in Finland) Työ- ja elinkeinoministeriön julkaisuja 2014. Työ ja yrittäjyys 6/2014.

[4] OECD Working Together: Skills and Labour Market Integration of Immigrants and their Children in Finland., Paris: OECD Publishing.2018. <https://doi.org/10.1787/9789264305250-en>.

[5] R. Kauppinen and M. Drake, "Virtual Reality in Competence Recognition for Immigrants," in Proceedings from the 14th International Technology, Education and Development Conference, 2020. INTED 2020. vol 1, pp. 5578-5582, 2020.

[6] R. Kauppinen, M. Drake, K. Anttila, and E. Lindgren, Implementing Virtual Reality Based Competence Recognition. IEEE 2021 Proceedings 19th International Conference on Information and Education Technology ICIET 2021.

[7] M. Drake \& Kauppinen, R. Developing Virtual Reality-based training materials in collaboration with higher education institutions and companies. EdUlearn21 Proceedings. $13^{\text {th }}$ international conference on education and new learning technologies $5^{\text {th }}-6^{\text {th }}$ of July 2021.

[8] S: Kavanagh, A. Luxton-Reilly, B. Wunche \& B Plimmer, A systematic review of Virtual Reality in education. Themes in Science \& Technology Education, vol. 10, no. 2, pp. 85-119.2017.

[9] J. L. McGrath, J. M. Taekman P. Dev, D. R. Danforth, D. Mohan, N. Kman, A. Crichlow, W. F. Bond. Using Virtual Reality Simulation Environments to Assess Competence for Emergency Medicine Learners. 2017. https://doi.org/10.1111/acem.13308.

[10] B. Dalgarno, J. Hedberg, and B. Harper, "The contribution of 3D environments to conceptual understanding," in Proceedings from the 19th Annual Conference of the Australasian Society for Computers in Learning in Tertiary Education, 2002. ASCILITE 2002. vol. 1, pp. 149-158, 2002.

[11] A. Kulik, A. Kunert, S. Beck, and B. Frölich, "Collaborative Virtual Reality for Joint Learning Experiences," in Proceedings from the 12th International Conference on Computer Supported Collaborative Learning, 2017. CSCL 2017. vol. 1, pp. 721-722, 2017.

[12] M. Melo, E. Bentley, K. McAllister, and J. Cortez, "Pedagogy of Productive Failure: Navigating the Challenges of Integrating VR into the Classroom," Journal of Virtual Worlds Research, vol. 12, no. 1, pp. 1-21, 2019.

[13] M. P. Wallach, R. Safir, E. Horef, E. Huber, and T. Heiman, "Presence in Virtual Reality. Importance and Methods to Increase It," Virtual Reality, March, 2012.

[14] World Economic Forum, "Jobs of Tomorrow: Mapping Opportunity in the New Economy," World Economic Forum, 2020. Retrieved from https://www.weforum.org/reports/jobs-of-tomorrowmapping-opportunity-in-the-new-economy-

[15] P. Hager and A. Gongzi, “What is Competence?” Medical Teacher, vol. 18, no. 1, pp. 15-18,1996.

[16] W. Lorin and D. Krathwohl (eds.), A Taxonomy for Learning, Teaching, and Assessing: A Revision of Bloom's Taxonomy of Educational Objectives. New York: Longman, 2001.

[17] R. J. Marzano and J. S. Kendall, The new taxonomy of educational objectives, 2nd ed. Thousand Oaks, CA: Corwin Press, 2007.

[18] R. Ryan and E. Deci, "Self-determination theory and the facilitation of intrinsic motivations, social development, and well-being," American Psychologist, vol. 55, 68-78, 2000. doi: 10.1037110003066X.55.1.68R.

[19] M. Pallot, B. Trousse, B. Senach, and D. Scapin, "Living Lab Research Landscape: From UserCentered Design and User Experience towards User Cocreation," First European Summer School 'Living Labs', 2010. Retrieved from https://hal.inria.fr/inria-00612632

[20] M. Westerlund and S. Leminen, "Managing the challenges of becoming an open innovation company: experiences from living labs," Technology Innovation Management Review, October, pp. 19-25, 2011. 
[21] Mehiläinen yrityksenä, 2021. Retrieved from https://www.mehilainen.fi/yritysinfo/mehilainenyrityksena.

[22] J. Wiles, Leading Curriculum Development. UK: Sage, 2009.

[23] Oculus, "Health and safety warnings," 2020. Retrieved from https://www.oculus.com/legal/healthand-safety-warnings/.

[24] Ruokavirasto.fi/hygieniapassi, 2021. Retrieved Https://www.ruokavirasto.fi/henkiloasiakkaat/hygieniapassi/. 